\title{
‡USGS
}

science for a changing world

Prepared for the National Aeronautics and Space Administration

\section{Geologic Map of the Hecate Chasma Quadrangle (V-28), Venus}

\author{
By Ellen R. Stofan, John E. Guest, and Antony W. Brian
}

Pamphlet to accompany

Scientific Investigations Map 3163

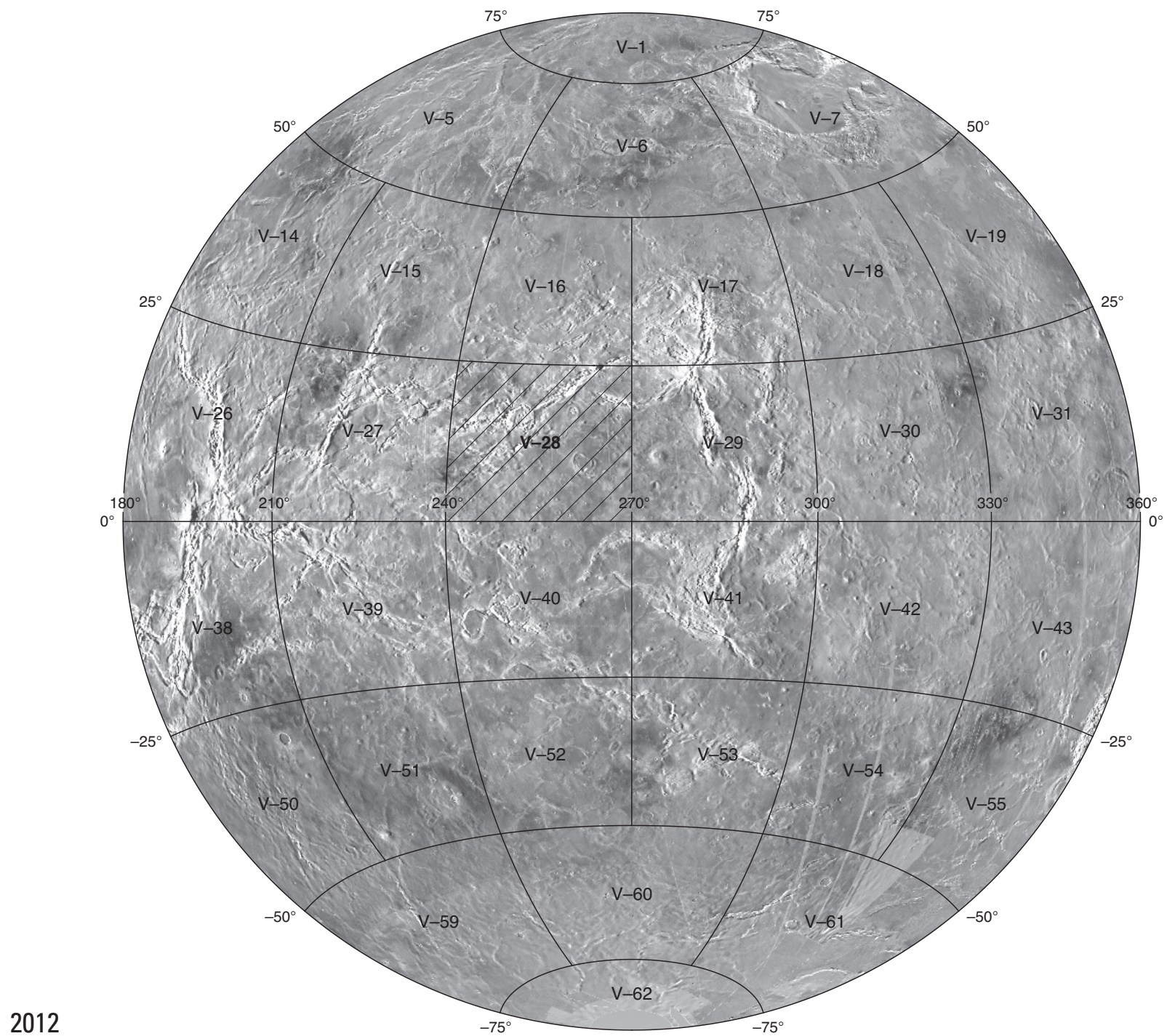

U.S. Department of the Interior

U.S. Geological Survey 
This page intentionally left blank 


\section{Contents}

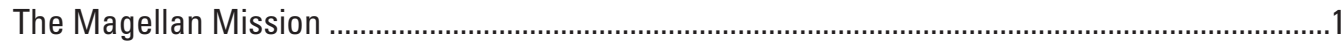

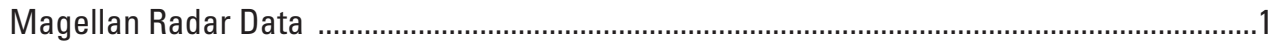

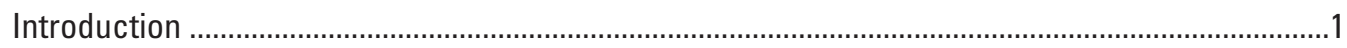

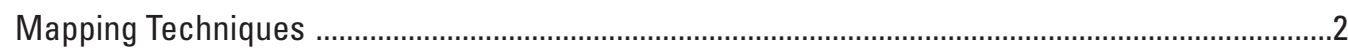

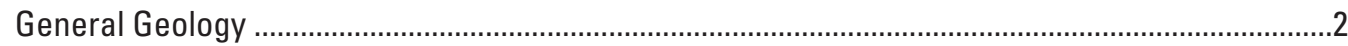

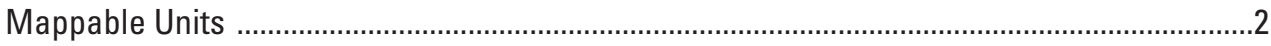

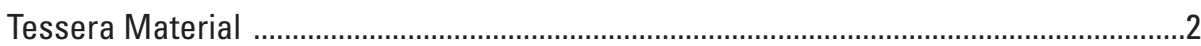

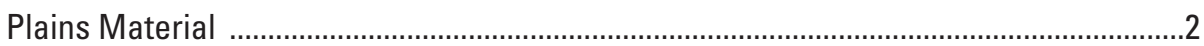

Volcanic Edifice and Flow Material .............................................................................

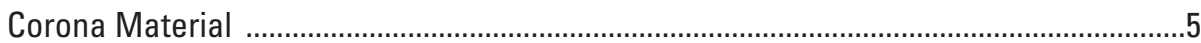

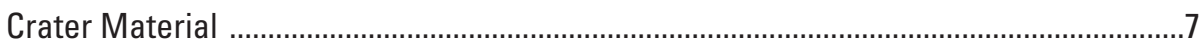

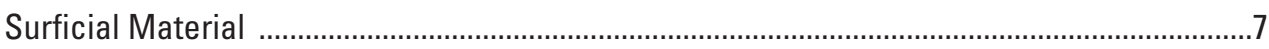

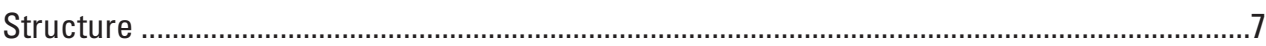

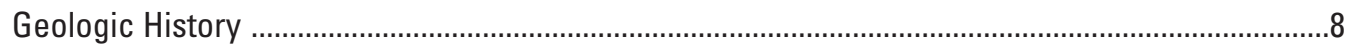

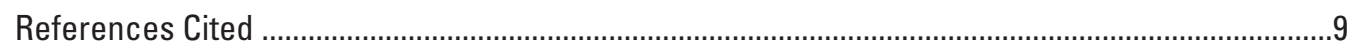

\section{Tables}

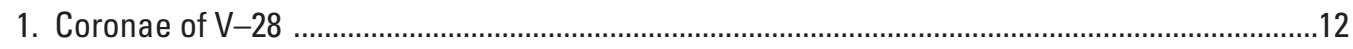

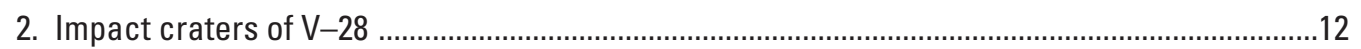

\section{Figures}

1. Magellan topographic map of quadrangle $\mathrm{V}-28$, extending from lat $0^{\circ}-25^{\circ} \mathrm{N}$., long $240^{\circ}-270^{\circ}$ E. (map sheet)

2. Magellan RMS slope roughness map of quadrangle $\mathrm{V}-28$, extending from lat $0^{\circ}-25^{\circ} \mathrm{N}$., long $240^{\circ}-270^{\circ}$ E. (map sheet)

3. Magellan emissivity map of quadrangle $\mathrm{V}-28$, extending from lat $0^{\circ}-25^{\circ} \mathrm{N}$., long $240^{\circ}-270^{\circ} \mathrm{E}$. (map sheet)

4. Portion of Hinemoa edifice plains material (unit peH) illustrating high concentration of small edifices within the unit, and the closely spaced lineaments that deform the unit (map sheet)

5. Edifice field material (unit ef), characterized by small edifices surrounded by radar-dark flow deposits (map sheet)

6. The volcano Kono Mons is cut in half by Zverine Chasma; the dashed lines indicate the location of the Zverine trough rim (map sheet) 
This page intentionally left blank 


\section{The Magellan Mission}

The Magellan spacecraft orbited Venus from August 10, 1990, until it plunged into the Venusian atmosphere on October 12, 1994. Magellan Mission objectives included (1) improving the knowledge of the geological processes, surface properties, and geologic history of Venus by analysis of surface radar characteristics, topography, and morphology and (2) improving the knowledge of the geophysics of Venus by analysis of Venusian gravity.

The Magellan spacecraft carried a $12.6-\mathrm{cm}$ radar system to map the surface of Venus. The transmitter and receiver systems were used to collect three data sets: (1) synthetic aperture radar (SAR) images of the surface, (2) passive microwave thermal emission observations, and (3) measurements of the backscattered power at small angles of incidence, which were processed to yield altimetric data. Radar imaging and altimetric and radiometric mapping of the Venusian surface were accomplished in mission cycles 1, 2, and 3 from September 1990 until September 1992. Ninety-eight percent of the surface was mapped with radar resolution on the order of $120 \mathrm{~m}$. The SAR observations were projected to a 75-m nominal horizontal resolution, and these full-resolution data compose the image base used in geologic mapping. The primary polarization mode was horizontal-transmit, horizontal-receive $(\mathrm{HH})$, but additional data for selected areas were collected for the vertical polarization sense. Incidence angles varied between about $20^{\circ}$ and $45^{\circ}$.

High-resolution Doppler tracking of the spacecraft took place from September 1992 through October 1994 (mission cycles 4, 5, 6). Approximately 950 orbits of high-resolution gravity observations were obtained between September 1992 and May 1993 while Magellan was in an elliptical orbit with a periapsis near $175 \mathrm{~km}$ and an apoapsis near 8,000 km. An additional 1,500 orbits were obtained following orbit-circularization in mid-1993. These data exist as a $75^{\circ}$ by $75^{\circ}$ harmonic field.

\section{Magellan Radar Data}

Radar backscatter power is determined by (1) the morphology of the surface at a broad range of scales and (2) the intrinsic reflectivity, or dielectric constant, of the material. Topography at scales of several meters and larger can produce quasi-specular echoes, and the strength of the return is greatest when the local surface is perpendicular to the incident beam. This type of scattering is most important at very small angles of incidence, because natural surfaces generally have few large tilted facets at high angles. The exception is in areas of steep slopes, such as ridges or rift zones, where favorably tilted terrain can produce very bright signatures in the radar image. For most other areas, diffuse echoes from roughness at scales comparable to the radar wavelength are responsible for variations in the SAR return. In either case, the echo strength is also modulated by the reflectivity of the surface material. The density of the upper few wavelengths of the surface can have a significant effect. Low-density layers, such as crater ejecta or volcanic ash, can absorb the incident energy and produce a lower observed echo. On Venus, a rapid increase in reflectivity exists at a certain critical elevation above which high-dielectric minerals or coatings are thought to be present. This leads to very bright SAR echoes from virtually all areas above that critical elevation.

The measurements of passive thermal emission from Venus, though of much lower spatial resolution than the SAR data, are more sensitive to changes in the dielectric constant of the surface than to roughness. They can be used to augment studies of the surface and to discriminate between roughness and reflectivity effects. Observations of the near-nadir backscatter power, collected using a separate smaller antenna on the spacecraft, were modeled using the Hagfors expression for echoes from gently undulating surfaces to yield estimates of planetary radius, Fresnel reflectivity, and root-mean-square (rms) slope. The topographic data produced by this technique have horizontal footprint sizes of about $10 \mathrm{~km}$ near periapsis and a vertical resolution on the order of $100 \mathrm{~m}$. The Fresnel reflectivity data provide a comparison to the emissivity maps, and the rms slope parameter is an indicator of the surface tilts, which contribute to the quasi-specular scattering component.

\section{Introduction}

The Hecate Chasma quadrangle (V-28) extends from lat $0^{\circ}$ to $25^{\circ} \mathrm{N}$. and from long $240^{\circ} \mathrm{E}$. to $270^{\circ} \mathrm{E}$. The quadrangle was mapped at 1:5,000,000 scale as part of the National Aeronautics and Space Administration (NASA) Planetary Geologic Mapping Program.

Hecate Chasma is an extensive rift system consisting of multiple branches (for example, Hamilton and Stofan, 1996) that lies in the lowland region of Hinemoa Planitia in the northern hemisphere of Venus. Here, we use the term "rift" and "chasma" (plural "chasmata") to designate the trough and fracture zones that make up the Hecate system. Lineaments within the Hecate rift system that define Hecate, Zverine, and Hanwi Chasmata are mapped in red for emphasis. The system consists of several rifts and fracture belts, low-lying plains units, coronae and numerous small volcanic edifices including shields, domes and cones. The three branches of the Hecate rift system in this quadrangle are Hecate Chasma (centered at lat $18.2^{\circ} \mathrm{N}$., long $254.3^{\circ}$ E.), Zverine Chasma (centered at lat $18.5^{\circ}$ N., long $271^{\circ}$ E.), and Hanwi Chasma (centered at lat $10.5^{\circ} \mathrm{N}$., long $247^{\circ}$ E.). The quadrangle also contains many intermediate to large volcanoes, including Polik-mana Mons and Nazit Mons. Eighteen coronae are located in the quadrangle (table 1), the largest of which is the $525 \mathrm{~km}$ across Taranga Corona, along with fourteen impact craters (table 2). Corona maximum widths are measured to the outer edge of the annulus (for example, Stofan and others, 1992). Lineaments that form the corona annulus are mapped in green for emphasis.

The overall topography of $\mathrm{V}-28$ consists of plains located slightly below mean planetary radius (MPR, 6051.84, Ford and Pettengill, 1992) (fig. 1). The lowest regions are found in the rift trough ( $3.3 \mathrm{~m}$ below MPR), and the highest along the rift rim (4.3 $\mathrm{km}$ above MPR). The regions that are the roughest at Magellan radar wavelengths in the quadrangle occur along Hecate Chasma (root mean square [rms] slopes $>10^{\circ}$ ), with 
most regions being relatively smooth (roughnesses comparable to the average Venus surface value of $2.84^{\circ}$, for example, Ford and Pettengill, 1992; Campbell and Campbell, 1992; Campbell, 1995) (fig. 2). Emissivity values in the quadrangle are typical of most venusian plains regions, with a range in values for the quadrangle of 0.68-0.91 (fig. 3). The highest emissivity values in the quadrangle lie at the highest elevations in the quadrangle (corona rims and interiors).

\section{Mapping Techniques}

Standard planetary geologic mapping techniques (for example, Wilhelms, 1972, 1990) were used to construct a geologic map of the V-28 quadrangle. Magellan synthetic aperture radar (SAR) data were used for the map base; SAR backscatter in the Magellan data vary primarily as a function of surface roughness at the scale of the radar wavelength $(12.6 \mathrm{~cm})$, as well as the surface topography and intrinsic reflectivity. Magellan altimetry, RMS slope, reflectivity and emissivity data sets (figs. 1-3, Pettengill and others, 1992; Campbell, 1995) provide additional information on the properties of map units.

Synthetic parallax stereo images with a 10x vertical exaggeration and full-resolution Magellan image mosaics (F-Maps) produced by the U.S. Geological Survey (USGS) (both print and digital data) were used extensively to identify embayment relations and truncation of structures at contacts, the primary methods by which we determined relative ages of units. In particular, embayment relations could be clearly seen in the synthetic stereo data. Unit character and boundary locations not resolvable at C1-MIDR scale (225 m/pixel) were clearly seen at F-Map scale ( $75 \mathrm{~m} /$ pixel) (actual radar resolution is about $120 \mathrm{~m}$ ). However, age relations determined with F-Maps are a function of the scale and nature of this radar data; age relations between units as well as their mechanism of formation are undoubtedly more complex (for example, Zimbelman, 2001). Apparently contradictory stratigraphic relations between major map units (that is, a unit appearing to be superposed by another unit in one place and superposed on the same unit in another location) were frequently found to be caused by the presence of additional subtle units only noticeable through digital manipulation of F-Map data.

For flow units tied to a particular source, subunits are numbered if stratigraphic relations between them could be determined (for example, $\mathrm{fNa}_{1-3}$ ); if not all units touched and therefore age relations are ambiguous, then subunits are lettered (for example, $\mathrm{fPo}_{\mathrm{a}-\mathrm{c}}$ ). F-Maps were also used to identify volcanic edifices, flow directions, and structures. Small volcanic edifices and structures are extremely numerous in this quadrangle, and thus are mapped in a representative fashion (Tanaka, 1994), with approximately one in ten features shown, although less than that in the chasmata troughs due to the close spacing of features in those regions.

There are other difficulties in using radar data to construct a geologic map (for example, Ford and others, 1993; Hansen, 2000). Geologic units will only be visible if they have backscatter characteristics distinctly different from the surrounding units, or if they can be defined by secondary structural relations (that is, embayment of secondary structures in unit 1 by unit 2). In plains regions or lava flow fields, younger and older units of similar backscatter may be mistakenly incorporated into a single unit. If the surface properties of a unit change laterally, potentially its radar signature can also change, and it may be mapped incorrectly as two or more units. In addition, structures tend to be more readily identified if they are oriented perpendicular to the radar look-direction (for example, Stofan and others, 1989). Thus, in Magellan data, $\mathrm{N}-\mathrm{S}$ trending lineaments will tend to be well defined, but E-W trending structures are likely to be underrepresented or only weakly represented in the image data unless they have associated rough talus slopes. We did use secondary structures to help define units, in particular to aid in defining boundaries between plains and flow units, although secondary structures must be used with caution (for example, Hansen, 2000).

\section{General Geology}

Six types of materials have been mapped in the V-28 quadrangle: plains, volcanic edifice and flow, corona, tessera, crater, and surficial materials. All types of material units occur throughout the quadrangle, with the exception of tessera materials, which crop out only in the northwestern part of the mapped region. All materials are mapped as units, except for surficial material (shown by stippled pattern).

\section{Mappable Units}

\section{Tessera Material}

Three outcrops of materials with two or more dominant fracture and (or) ridge orientations were mapped as tessera material (unit t) (Hansen and Willis, 1996, 1998; Hansen, 2006), following the convention for Venus (Tanaka, 1994), while units with a single or very dominant direction of fractures were mapped as unit pfH or unit peH. Tessera materials tend to be relatively radar-bright or rough at the Magellan radar wavelength $(12.6 \mathrm{~cm})$, and stand higher than the surrounding units (Barsukov and others, 1986). We interpret the tessera unit to represent locally older tectonically deformed regions, embayed by younger volcanic plains and flows. The outcrops in this region are too small to determine if the complex deformation was produced in a single event or multiple events, nor can we determine if all of the outcrops formed in the same event. Deformation at these fragments is similar to deformation in the interior of some coronae; some tessera fragments could be kipukas of corona materials, as suggested previously by Hansen and Willis (1996). The three outcrops of unit $t$ lie to the north of Hecate Chasma and are embayed by unit $\mathrm{pA}$, unit $\mathrm{psH}$, unit $\mathrm{pcH}$, unit $\mathrm{phH}$, and unit $\mathrm{fT}_{\mathrm{b}}$.

\section{Plains Material}

We identified nine plains material units in the Hecate Chasma quadrangle (from oldest to youngest): Hinemoa frac- 
tured plains material (unit pfH), Hinemoa edifice plains material (unit peH), Hinemoa uniform plains material (unit puH), Hinemoa hummocky plains material (unit phH), Hinemoa mottled plains material (unit pmH), Hinemoa composite-flow plains material (unit pcH), Asteria plains material (unit pA), Hinemoa smooth plains material (unit psH), and Hinemoa lobate plains material (unit plH). Each of the plains units are composed of many small plains units of varying age, which are grouped into a mappable unit owing to their similarity in geomorphology and stratigraphic position relative to other plains units. Some of the plains units, including units $\mathrm{pfH}, \mathrm{peH}$, and $\mathrm{plH}$, tend to crop out as isolated patches of materials. Plains units on Venus are interpreted to be volcanic in origin, owing to their similarity to volcanic plains on other planets (for example, Masursky and others, 1980; Barsukov and others, 1986), surface chemical compositions and images obtained by the Venera landers (for example, Surkov and others, 1984), and the lack of water on the planet for at least 2-3 billion years (Kasting and Pollack, 1983) making a sedimentary origin unlikely. All of the plains units except unit psH and unit $\mathrm{plH}$ are cut by closely spaced $(<10 \mathrm{~km})$, sinuous lineaments that we interpret to be polygonal fractures (for example, Smrekar and others, 2002).

The Hinemoa fractured plains material (unit pfH) is the oldest local plains unit in the V-28 quadrangle. It is usually high standing, and typically occurs in small patches. We do not know if this unit represents a single time stratigraphic unit, or is an amalgam of different ages of kipukas of fractured plains. Unit peH, Hinemoa edifice plains material, is also typically high standing, and is younger than the outcrops of unit $\mathrm{pfH}$ with which it is in contact (which does not include all outcrops of unit pfH). Unit peH has a high abundance of small edifices, wrinkle ridges and fractures (fig. 4). To determine the relative ages of small edifices within the unit, we looked for crosscutting relations with secondary structures and superposition relations, similar to the method of Ivanov and Head (2004) (their criteria $1-3,9,10-12)$, and Addington (2001). However, Ivanov and Head (2004) relate ages of edifice fields to a unit 'regional plains with wrinkle ridges', which is not present in this quadrangle. Edifices within unit $\mathrm{peH}$ are both superposed on and cut by secondary structures. The small edifices deposits may have contributed to the formation of this plains unit, but the fact that they also superpose secondary structures indicates that their formation persisted after formation of the unit (fig. 4). If small edifices have mappable deposits, they were grouped into unit ef (fig. 5, described below). In the neighboring $\mathrm{V}-40$ quadrangle, unit peH corresponds to unit $\mathrm{f} 2$ (flow materials) (Chapman, 1999). Unit peH is embayed by units $\mathrm{phH}, \mathrm{pmH}, \mathrm{puH}$, and $\mathrm{psH}$. Based on the lobate boundaries and abundant volcanic edifices within this unit, we interpret unit peH to be composed of multiple materials of volcanic origin, with the abundant small edifices within the unit forming over an unknown time span.

Hinemoa uniform plains material (unit puH) and Hinemoa hummocky plains material (unit $\mathrm{phH}$ ) are two of the most widespread plains units in the $\mathrm{V}-28$ quadrangle. Unit $\mathrm{puH}$ is relatively homogeneous, with few edifices or fractures, and is located primarily in the southeastern portion of the quadrangle. The Hinemoa hummocky plains material (unit phH) occurs primarily in the western portion of the quadrangle, and includes much of the Hecate rift system. Unit phH has a mottled texture, is cut by faults from the rifts, and has some flows and edifices. Unit puH is embayed by unit phH. Units puH and phH embay units $\mathrm{peH}$ and $\mathrm{pfH}$. Corona and volcano flow materials superpose $\mathrm{phH}$, which in turn is deformed by lineaments associated with Hecate Chasmata. These plains materials are interpreted to be volcanic in origin based on the identification of diffuse flow fronts within the units and their lobate boundaries.

Hinemoa mottled plains material, (unit $\mathrm{pmH}$ ) located in the southern portion of the quadrangle, tends to be topographically higher than surrounding units. It has abundant small edifices and sub-unit-scale flow materials. It may be higher standing than surrounding plains units due to volcanic construction or uplift. Along the southern boundary of $\mathrm{V}-28$, unit $\mathrm{pmH}$ contacts correspond to units pd and $\mathrm{pl}$ (radar-dark and radarlight plains, respectively) mapped in V-40 quadrangle (Chapman, 1999). Unit pmH superposes units $\mathrm{peH}$ and $\mathrm{puH}$, and is superposed by flow units associated with a corona and several volcanic features.

The Hinemoa composite-flow plains material (unit $\mathrm{pcH}$ ) is located in the northwestern portion of the quadrangle, and is composed of multiple small-scale flow materials. Fractures associated with coronae and volcanoes cut the unit. Unit $\mathrm{pcH}$ superposes units $\mathrm{pfH}, \mathrm{pA}$, and $\mathrm{phH}$ and is superposed by unit $\mathrm{psH}$ and several flow units originating from volcanoes.

Asteria plains material (unit $\mathrm{pA}$ ), in the northern portion of the quadrangle, is cut by faults from Hecate and Zverine Chasmata. Unit pA is composed of smaller scale flow materials $(<100 \mathrm{~km}$ across, with indistinct boundaries), and some small edifices. Unit pA embays units $\mathrm{phH}$, peH, and $\mathrm{pfH}$, but does not come into contact with unit puH. Unit pA is embayed by corona and flow materials.

The youngest plains units in the $\mathrm{V}-28$ quadrangle are units $\mathrm{psH}$ and $\mathrm{plH}$. The Hinemoa smooth plains material (unit $\mathrm{psH}$ ) forms in patches typically hundreds of kilometers across, and has a sheet-like or homogeneous appearance. Unit $\mathrm{plH}$ (Hinemoa lobate plains material) occurs in two small $(<200 \mathrm{~km}$ across) patches in the north-central portion of the map, superposed on unit $\mathrm{pA}$. The unit has small edifices, and superposes lineaments of Zverine Chasma. Outcrops of units $\mathrm{psH}$ and $\mathrm{plH}$ tend to be small ( $<300 \mathrm{~km}$ across), and occur on opposite sides of $\mathrm{V}-28$. Units $\mathrm{psH}$ and $\mathrm{plH}$ are interpreted to be volcanic in origin, owing to their typically lobate boundaries and association with edifices. The units are defined based on radar brightness and texture, and therefore outcrops of the same unit may or may not have formed at the same time. Unit plH superposes unit $\mathrm{pA}$ and is not in contact with any other units. Unit $\mathrm{psH}$ superposes units $\mathrm{phH}, \mathrm{pA}$, and $\mathrm{pcH}$, and is superposed by Leyster and Nuriet impact craters, Hecate Chasma flows, and flows from a volcano and several coronae.

Plains units in the V-28 quadrangle are interpreted to be volcanic in origin (for example, Saunders and others, 1991; Head and others, 1992), as most units have lobate boundaries and abundant small edifices. Flows and groups of flows comprise each unit, but are not mapped as separate units as their boundaries can rarely be closed. Only the smooth and lobate plains units (units $\mathrm{psH}$ and $\mathrm{plH}$ ) are sheet-like and homogeneous in appearance. All of the plains units are cut by linea- 
ments, most of which we interpret to be extensional fractures based on their linearity. Few wrinkle ridges occur in V-28, being limited to units south of the Hecate rift system, and typically deforming unit peH.

\section{Volcanic Edifice and Flow Material}

The Hecate Chasma quadrangle contains a variety of mappable units associated with volcanic landforms including several large shield volcanoes (Nazit Mons, lat 22.5 ${ }^{\circ}$., long $240.1^{\circ}$ E.; Polik-mana Mons, lat $24.8^{\circ}$ N., long $264^{\circ}$ E.; Kono Mons, lat $18^{\circ} \mathrm{N}$., long $268^{\circ} \mathrm{E}$.; and the western half of Xochiquetzal Mons, lat $3.5^{\circ} \mathrm{N}$., long $270^{\circ} \mathrm{E}$.), numerous intermediate volcanoes, abundant small volcanic edifices and a large flow field. Few of the units associated with these edifies are in contact with each other. The unusually high concentration of volcanic features in this quadrangle is consistent with it being located within the Beta-Atla-Themis zone, the highest concentration of volcanic features on Venus (Crumpler and others, 1997).

Volcanic complex material (unit vc) delineates material associated with fourteen unnamed volcanic centers. Unit vc typically consists of a 5- to 50-km-diameter edifice (caldera or topographic high) surrounded by an apron of flow material that varies in extent from the edifice summit. Other occurrences of unit vc lack a distinct edifice. Unit vc overlies units $\mathrm{phH}, \mathrm{fPa}$, $\mathrm{pcH}$, ef, pmH, plH, pfH, peH, $\mathrm{fSi}_{\mathrm{b}}$, and $\mathrm{pA}$, and is overlain by units $f A l, f M, f A r_{b}, f N T_{1}, p s H$, and $f G$. One volcanic center is cut by chasma fractures.

Shulzenko Patera material (unit fSh) is associated with a $60-\mathrm{km}$-across depression surrounded by flow materials. Shulzhenko Patera material is overlain by Lama Tholus material (unit fL) and Aruru Corona materials (units $f \mathrm{Ar}_{\mathrm{a}}, \mathrm{b}$ ), but overlies Hinemoa uniform plains material (unit puH).

Edifice field material (unit ef) consists of clusters of small edifices with diameters of 5-20 km (for example, Guest and others, 1992). The unit is mapped due to its higher concentration of edifices than surrounding units, because it has mappable boundaries, and on the assumption that the edifices share a common source and (or) are stratigraphically related (fig. 5). We are limited in our ability to determine age relations between individual edifices within a field as the fields are generally lacking in secondary structures; the edifices formed over some unknown time period. Each field contains numerous small edifices, some only identifiable as pits. Unit ef is overlain by units $\mathrm{fX}, \mathrm{fSi}_{\mathrm{b}}, \mathrm{fAr}_{\mathrm{a}}$, and $\mathrm{vc}$ and overlies units $\mathrm{pfH}, \mathrm{plH}, \mathrm{pcH}$, and peH. It both overlies and is overlain by unit phH and unit $\mathrm{pA}$, demonstrating that this unit is not representative of a single time-stratigraphic unit, but represents a morphologic grouping of units of differing ages.

Hecate Chasma flow material (unit $\mathrm{fH}$ ) is mapped in four places along the Hecate system. The occurrences consist of digitate to sheet-like deposits located at the chasma topographic rim that are interpreted to have erupted from fissures associated with the chasma. Unit $\mathrm{fH}$ overlies units $\mathrm{pA}, \mathrm{psH}$, and $\mathrm{phH}$ and is overlain by units $\mathrm{fPb}$ and $\mathrm{fGK}_{1-2}$.

At Nazit Mons (350 km diameter), superposition relations determined from FMap and stereo data permit a sequence of flow units associated with the volcano to be mapped (Nazit
Mons flow material members 1-3, units $\mathrm{fNa}_{1-3}$ ), although each of these Nazit flow units likely represent flow complexes rather than individual flows (that is, Stofan and others, 2001a). Flows associated with Nazit Mons (units $\mathrm{fNa}_{1-2}$ ) overlie corona flow unit $\mathrm{fAc}_{1}$, as well as plains units $\mathrm{pcH}$, $\mathrm{pfH}$, and $\mathrm{phH}$.

The quadrangle contains a fluctus or flood lava deposit, Sobra Fluctus material (unit fSo). The unit lies just to the south of the southern branch of Hecate Chasma, and covers approximately $150,000 \mathrm{~km}^{2}$. The material emanated from either fractures associated with the chasma, or from a depression located within the unit at lat $5.1^{\circ} \mathrm{N}$., long $248^{\circ} \mathrm{E}$. The unit consists of lobate materials of intermediate brightness, with some darker flows along the southern margin. Unit fSo overlies unit $\mathrm{phH}$, unit peH, and unit puH and is overlain by flows from Rind Corona. The flow deposit is cut by chasma-related fractures. Over 200 large flow fields have been identified elsewhere on Venus (for example, Roberts and others, 1992; Lancaster and others, 1995), and are interpreted to form from lithospheric extension accompanied by decompression melting of the mantle (Magee and Head, 2001), a likely mechanism for this flow deposit owing to its proximity to Hecate Chasma.

Tholi are small domical hills or mountains. Nipa and Iaso Tholi have a central vent surrounded by flows of varying backscatter, with diameters of 140 and $30 \mathrm{~km}$, respectively. Nipa Tholus material (unit fNi) overlies units phH and fAE. Iaso Tholus has two mappable deposits: Iaso Tholus material members 1 and 2 (units fIa 1 and fIa 2 ). Unit fIa 2 is superposed on unit fIa 1 , with the flow units superposed on units $\mathrm{puH}, \mathrm{peH}$, $\mathrm{phH}$, and $\mathrm{pmH}$.

Garbo Patera flow material (unit fG) is associated with a 75-km-diameter, circular depression surrounded by concentric fractures interpreted as a caldera. The flow material extends for about $100 \mathrm{~km}$. Unit $\mathrm{fG}$ overlies units vc, $\mathrm{pmH}$, and $\mathrm{phH}$, and is overlain by another unit vc, and units $\mathrm{psH}$ and $\mathrm{fM}$.

Paoro Tholi material is divided into two members (units $\mathrm{fPa}_{1-2}$ ) that are associated with two overlapping shields with a diameter of $225 \mathrm{~km}$. Observations of stereo images and full resolution radar images indicate that deposits from the eastern center (unit $\mathrm{fPa}_{2}$ ) overlie flows from the western center (unit $\mathrm{fPa}_{1}$ ). However, based on the complex nature of the boundary between the two centers, it is likely that they were active simultaneously. Unit $\mathrm{fPa}_{1}$ overlies units $\mathrm{peH}$ and $\mathrm{fAr}_{\mathrm{b}}$; unit $\mathrm{fPa} 2$ overlies units peH and puH and is overlain by unit vc.

Polik-mana Mons is a large volcano (600 km diameter) situated directly on Hecate Chasma. Associated with the edifice are three units: Polik-mana material members a-c (units $\mathrm{fPO}_{\mathrm{a}-\mathrm{c}}$ ). Age relations of flow units at Polik-mana Mons are difficult to determine, with the exception of unit $\mathrm{fPo}_{\mathrm{C}}$, which overlies adjacent unit $\mathrm{fPo}_{\mathrm{a}}$ flows. The flow materials are largely superposed on the rift, but unit $\mathrm{fPO}_{\mathrm{a}}$ flows have been cut by rift fractures, suggesting that the volcano formed contemporaneously with the chasma. Flows from Polik-mana Mons overlie plains unit $\mathrm{pA}$ and unit $\mathrm{fH}$.

Ixtab Mons is an $80-\mathrm{km}$-diameter topographic edifice with a summit caldera, located on the topographic rim of Hecate Chasma. Ixtab Mons material (unit fIx) overlies units $\mathrm{phH}$, $\mathrm{psH}$, and flows from Hecate Chasma, and is superposed and cut by chasma-parallel fractures. Lama Tholus (110 km diameter) 
has a central vent surrounded by radiating flow deposits. Lama Tholus flow material (unit fL) overlaps flows from Shulzhenko Patera (unit fSh) and plains units puH and peH. Flows from Lama Tholus are overlain by flows from Aruru Corona (unit $\left.f A r_{b}\right)$ and the crater Alina.

The volcano Xochiquetzal Mons ( $80 \mathrm{~km}$ diameter), is located outside the quadrangle at lat $3.5^{\circ} \mathrm{N}$., long $270^{\circ} \mathrm{E}$., but has flow units that extend into $\mathrm{V}-28$. Xochiquetzal flow material (unit $f X$ ) superposes units $\mathrm{puH}$, plH, ef, and pfH.

Alcyone Tholus is a $70-\mathrm{km}$ diameter intermediate volcano with associated flow deposits that lies outside the quadrangle, at lat $2^{\circ} \mathrm{S}$, long $256.5^{\circ} \mathrm{E}$., in quadrangle $\mathrm{V}-40$. Alcyone flow material (unit $\mathrm{fAl}$ ) overlies unit $\mathrm{pmH}$, and is overlain by Miti Corona material (unit $\mathrm{fM}$ ). In the adjacent quadrangle $\mathrm{V}-40$, Chapman (1999) mapped these two units as one unit, unit cp4 (patera materials).

Wyrd Mons (150 km diameter) is a topographic edifice with a summit caldera, surrounded by radiating flows, located on the topographic rim of Hecate Chasma. Wyrd Mons material (unit fW) overlies flows from Taranga Corona (unit $\mathrm{fT}_{\mathrm{b}}$ ), unit $\mathrm{psH}$ and unit $\mathrm{phH}$, and is both superposed and cut by chasmaparallel fractures.

Serova Patera (60 km diameter) lies to the north of Hecate Chasma, and consists of a circular, rimmed caldera surrounded by a digitate flow apron. Serova Patera material (unit fSe) overlie flows from Taranga Corona (unit $\mathrm{fT}_{\mathrm{b}}$ ), plains units $\mathrm{puH}$ and $\mathrm{pcH}$, and the crater Johanna.

The volcano Kono Mons (350 km diameter) is cut by the trough of Zverine Chasma (fig. 6). Kono Mons flow material (unit $\mathrm{fK}$ ) overlies unit $\mathrm{pA}$ and the crater Baranamtarra. Pajan Yan Tholus ( $80 \mathrm{~km}$ diameter) is an intermediate shield with central vent surrounded by radiating flow deposits. Pajan Yan Tholus material (unit fPY) overlies material from Ak-Ene Corona (unit fAE) and units puH and phH.

Some of the volcanic units described above are directly superposed on the chasmata, whereas most lie in the plains to the north and south of the chasma system. The plains units to the south of Hecate Chasma are characterized by an abundance of small edifices, particularly in units $\mathrm{peH}$ and $\mathrm{pmH}$. Of the four large volcanoes in the quadrangle, two are superposed directly on the chasma, whereas two lie off the chasma. Formation of the chasma system and volcanism overlapped in time. Although it is clear that extension played a role in volcanism (for example, Magee and Head, 2001) for flow units along the rift such as Sobra Fluctus, the bulk of the volcanic units in this region lie to the south of the chasmata.

\section{Corona Material}

Eighteen coronae, ranging in maximum width from 125 to $525 \mathrm{~km}$, are located in the V-28 quadrangle (table 1), as well as flows from a nineteenth corona, Miti Corona, located outside the quadrangle. Of the eighteen coronae located within the quadrangle, ten have associated mappable deposits. Based on the classification scheme of Stofan and others (1992), eleven are classified as concentric coronae, three are concentric-double ring, one is a multiple corona, and three are asymmetric coronae. Most of the coronae (12 out of 18) are located along the chasma system, although only six lie directly on the fractures and troughs. Some of the coronae (for example, Taranga) have associated radial fractures that have been termed novae by other workers (Aittola and Raitala, 2005). Coronae topographic expression varies; some coronae such as Taranga and Aruru are large plateaus, and others, such as Prthivi Corona, are depressions. Few of the material units associated with coronae are in direct contact with other corona units, or with similar units (that is, all in contact with $\mathrm{phH}$, for example), resulting in difficulty in determining how the formation of all of the coronae in this quadrangle fits into the overall history of $\mathrm{V}-28$.

The coronae with no mappable deposits have concentric fractures that deform units $\mathrm{fT}_{\mathrm{b}}, \mathrm{phH}, \mathrm{pA}$, $\mathrm{peH}$, and $\mathrm{pmH}$. These structures are located both along the chasmata and in the plains regions surrounding the chasmata. Three of the coronae with no mappable units lie along Hanwi Chasma, and all three are depressions or rimmed depressions. The feature at lat $0.7^{\circ}$ $\mathrm{N}$, long $254.8^{\circ} \mathrm{E}$. does have structures that cut units peH and $\mathrm{pmH}$, but is also partially overlain by flows within these units, suggesting that the formation of coronae and the chasma system has overlapped in time.

Taranga Corona is a rimmed plateau superposed on Hecate Chasma, with extensive flow deposits mapped as Taranga Corona material, members a and $b$ (units $\mathrm{fT}_{\mathrm{a}-\mathrm{b}}$ ). It is the largest corona in the quadrangle, with a maximum width of $525 \mathrm{~km}$. Unit $\mathrm{fT}_{\mathrm{b}}$ overlies tessera material (unit t) and units $\mathrm{pfH}, \mathrm{phH}$, $\mathrm{pcH}$, and $\mathrm{pA}$. Taranga Corona materials are overlain by Gashan$\mathrm{Ki}$ Corona material (unit $\mathrm{fGK}_{1}$ ), Prthivi Corona material, and units $\mathrm{fW}$ and $\mathrm{fSe}$. It is also superposed by Johanna and Beecher impact craters. The most extensive unit of Taranga Corona material (unit $\mathrm{fT}_{\mathrm{b}}$ ) may be composed of multiple materials, but much of the unit's character is obscured by faults of Hecate Chasma. Similarly, the high plateau of the corona is also intensely deformed, and is mapped as a single unit, Taranga Corona material member a (unit $\mathrm{fT}_{\mathrm{a}}$ ) as it has a distinct, mappable boundary with Taranga Corona material member $\mathrm{b}$ (unit $\mathrm{fT}_{\mathrm{b}}$ ). In places unit $\mathrm{fT}_{\mathrm{a}}$ superposes unit $\mathrm{fT}_{\mathrm{b}}$ as it embays and superposes secondary structures that cut unit $\mathrm{fT}_{\mathrm{b}}$, but along much of the boundary the age relation is uncertain. An apparent volcanic center with a small ( $\sim 10 \mathrm{~km}$ across) summit depression interpreted as a caldera is located at lat $17^{\circ} \mathrm{N}$, long $252.5^{\circ} \mathrm{E}$. in the interior of Taranga. Although formation of the plateau-shaped topography of the corona postdated formation of Hecate Chasma, superposition of chasma fractures on corona-related flows indicate that formation of Hecate and Taranga overlapped in time.

Acrea Corona lies in the northwestern corner of the quadrangle and consists of a rimmed depression surrounded by multiple rings of concentric fractures. Its maximum width is $500 \mathrm{~km}$. An interior flow unit, Acrea Corona material, member 2 (unit $f A_{2}$ ), lies in a central topographic low, and is surrounded by apparently older, heavily fractured flow unit, Acrea Corona material, member 1 (unit $f A_{1}$ ). Some of the fractures cutting unit $f A c_{1}$ are regional fractures while others are related to the corona. Unit $\mathrm{fAc}_{1}$ overlies unit $\mathrm{pcH}$ and unit $\mathrm{pA}$ and is overlain by flows from Nazit Mons.

Tari Pennu Corona (200 km maximum width) lies along the southern margin of the V-28 quadrangle. It has a few, faint concentric fractures and a low, discontinuous topographic rim. 
Two flow units are mapped associated with the corona, Tari Pennu, material members 1 and 2 (units fTP $1-2$ ). Unit fTP $_{2}$ superposes earlier corona flows (unit TTP $_{1}$, mapped as corona materials in the adjacent quadrangle V-40 (Chapman, 1999)). Both corona material units superpose plains units $\mathrm{puH}$ and $\mathrm{pmH}$.

Nei-Teukez Corona lies in the plains to the south of Hanwi Chasma and is a rimmed depression with a diameter of $125 \mathrm{~km}$. Flow materials associated with Nei-Teukez Corona are split into two units, with a younger interior unit Nei-Teukez, material member 2 (unit $\mathrm{fNT}_{2}$ ) filling the central depression and an outer flow unit, Nei-Teukez, material member 1 (unit fNT 1 ). Unit $\mathrm{fNT}_{1}$ is overlain by one of the flow units from Sinlaku Corona (unit $\mathrm{fSi}_{\mathrm{b}}$ ), a volcanic center and unit $\mathrm{pmH}$. Unit $\mathrm{fNT}_{1}$ overlies units phH and peH.

Gashan-Ki Corona materials (units $\mathrm{fGK}_{1-2}$ ) are located just to the north of the southern arm of the Hecate rift, Hanwi Chasma. Gashan-Ki Corona has a somewhat irregular shape, with an outer rim and an irregular raised interior, and has a maximum width of $290 \mathrm{~km}$. A later flow unit (unit $\mathrm{fGK}_{2}$ ) superposes unit $\mathrm{fGK}_{1}$ and is radial to it, and is interpreted to have originated from fractures of the corona. Gashan-Ki materials (units $\mathrm{fGK}_{1-2}$ ) overlie unit $\mathrm{fT}_{\mathrm{b}}$, unit $\mathrm{fH}$ and unit $\mathrm{phH}$, and are both cut by and superpose lineaments associated with Hecate Chasma.

Aruru Corona materials (units $\mathrm{fAr}_{\mathrm{a}-\mathrm{d}}$ ), located in Hinemoa Planitia to the south of the Hecate and Zverine rifts, are extensive radiating sheet-like and digitate deposits associated with Aruru Corona. Aruru Corona is a rimmed plateau (450 by $350 \mathrm{~km}$ ), with folds on the southwestern margin. A small edifice with extensive flow material (unit $f \mathrm{Ar}_{\mathrm{C}}$ ) is located in the interior of the corona. This interior unit is surrounded by extensive deposits, Aruru Corona material, member b (unit fArb). Two additional corona-associated units were mapped: unit $f A r_{d}$, which extends from a source on the flanks of Aruru, and unit $f_{A}$, a flow radial to the corona that predates fArb. Aruru material unit $\mathrm{fAr}_{\mathrm{a}}$ overlies units $\mathrm{puH}$ and $\mathrm{fSh}$, and is overlain by $f A r_{b}$. Unit $f A r_{b}$ overlies unit $f A r_{a}$, plains units $p f H, p e H, p h H$, $\mathrm{puH}$, and $\mathrm{pmH}$, and volcanic units $\mathrm{fSh}$ and vc. Unit $\mathrm{fAr}_{\mathrm{b}}$ is overlain by units $\mathrm{psH}, \mathrm{fAr} r_{\mathrm{C}}, \mathrm{fAr} d \mathrm{fL}$, and $\mathrm{fPa}_{1}$. Units $\mathrm{fAr}_{\mathrm{C}}$ and $f A r_{d}$ are not in contact with any units other than $f \mathrm{Ar}_{b}$, which they overlie. Studies of the gravity signature of Aruru indicate that the corona is not currently active (Kiefer and Peterson, 2003).

Sinlaku Corona lies just to the south of the junction of the Hecate rift and Zverine Chasma. The corona is a $300 \mathrm{~km}$ across rimmed plateau, although unlike most rimmed coronae, the topographic rim has few associated fractures or ridges. Four units, Sinlaku Corona material, members a, b, c, and d (units fSia-d), are mapped associated with the corona. The outer deposits of Sinlaku Corona are sheet-like, whereas flows from the southern half of the coronae are digitate. Unit $\mathrm{fSi}_{\mathrm{a}}$ is superposed by units $f \mathrm{i}_{b-d}$. Unit $f \mathrm{Si}_{\mathrm{b}}$ is overlain by flows from an unnamed volcanic center and unit $f \mathrm{Si}_{d}$. Sinlaku unit $f \mathrm{Si}_{\mathrm{b}}$ superposes unit $\mathrm{phH}, \mathrm{psH}, \mathrm{pmH}, \mathrm{pA}$, and flows from Nei-Teukez Corona (unit $f \mathrm{NT}_{1}$ ). Unit $\mathrm{fSi}_{\mathrm{c}}$ overlies unit $\mathrm{fSi}_{a}$; unit $\mathrm{fSi}_{\mathrm{d}}$ overlies unit $\mathrm{fSi} \mathrm{i}_{\mathrm{b}}$.

Ak-Ene Corona (maximum width $150 \mathrm{~km}$ ) has a topographic rim and a flat interior, and lies in the plains south of Hanwi Chasma. Ak-Ene Corona material (unit fAE) overlies units $\mathrm{phH}$ and $\mathrm{fT}_{\mathrm{b}}$ and $\mathrm{puH}$ and is overlain by flows from Nipa and Pajan Yan Tholi. Ak-Ene was described as a relatively old corona by Aittola and Raitala (2005), but they did not recognize the flow deposits surrounding the corona.

The three youngest coronae in the quadrangle are Prthivi, Miti, and Rind Coronae. Prthivi Corona (diameter $300 \mathrm{~km}$ ) is a rimmed depression that lies directly on Hanwi Chasma and to the east of Gashan-Ki Corona, deforming phH. Prthivi material (unit $\mathrm{fPr}$ ) overlies unit $\mathrm{fT}_{\mathrm{b}}$ and unit $\mathrm{phH}$. Flows from Prthivi are cut by lineaments associated with Hecate Chasma, but flow units from the corona superpose other sets of chasma-parallel fractures. Three more coronae that are depressions lie along Hanwi Chasma to the northeast of Prthivi Corona.

Miti Corona (180 km across) is a corona that lies to the south of the quadrangle, at lat $3.5^{\circ} \mathrm{S}$, long $259.8^{\circ} \mathrm{E}$. Miti Corona material (unit $\mathrm{fM}$ ) superposes units $\mathrm{puH}, \mathrm{fG}, \mathrm{fAl}$, and vc. Rind Corona is a rimmed depression (maximum width 150 $\mathrm{km}$ across) located in the plains south of Hanwi Chasma. Rind Corona material (unit $\mathrm{fR}$ ) superposes units $\mathrm{phH}$ and $\mathrm{fSo}$.

In the $\mathrm{V}-28$ quadrangle, six coronae lay directly on the chasmata and the other twelve are located near the chasmata ( $<1000 \mathrm{~km}$ away). This is similar to Parga Chasma, where coronae are found in a high concentration near the chasma but not necessarily superposed on it (Martin and others, 2007). For those coronae in contact with chasmata in $\mathrm{V}-28$, we find evidence from faults and flows associated with Gashan-Ki and Prthivi Coronae (described above) that chasma formation and corona formation have overlapped in time. Taranga Corona is a notable exception, where the corona is superposed on Hecate Chasma, and thus formed after formation of Hecate (Hamilton and Stofan, 1996). Most, but not all, coronae have associated flow units that are younger than the plains in which they lie. Few units associated with volcanoes and coronae are in direct contact with one another, so very little relative age information of the timing of coronae in relation to volcano formation can be determined in this quadrangle. Where they are in direct contact, no specific sequence of formation can be determined. For example, flows from Serova Patera overlie flows from Taranga Corona, but flows from Paoro Tholi overlie flows from Aruru Corona. In turn, flows from Aruru Corona overlie Lama Tholus and Shulzhenko Patera. However, as it is only the outermost flow units that provide these age relations; all of these features may have been active concurrently. We interpret the overall spatial correlation of coronae and the chasma to indicate a related mechanism of formation, although coronae are forming over a broader region (500-1000 km) than Hecate Chasma itself (80-300 km), similar to Parga Chasma (Martin and others, 2007).

The coronae in quadrangle $\mathrm{V}-28$ have a great variation in topographic form, typical of most regions on Venus (Squyres and others, 1992a; Stofan and others, 1997; Stofan and others, 2001b). However, it is interesting to note that Hanwi Chasma, to the south of Hecate Chasma, has coronae along it that are all depressions or rimmed depressions. This consistent pattern of corona topography (in this case depressions) along Hanwi Chasma was not identified on any of the fifteen branches of the Parga rift system (Martin and others, 2007), but may exist at other chasmata on Venus. 
Coronae in this quadrangle also vary greatly in the apparent extent of associated volcanism. Associated volcanism includes interior (of the corona rim) and exterior (extending from the corona rim) flows and small to intermediate edifices located in the center of the corona. On the basis of morphology and similarity to flows associated with volcanic edifices, we interpret these flows to be volcanic in origin. Previous workers have determined that coronae in rift zones tend to have increased amounts of flow, interpreted to be the result of the intersection of upwelling with an extensional zone (Magee and Head, 1995). We find that coronae with high amounts of associated flows (Sinlaku, Aruru Coronae) are just as likely to lie off the rift as on (Taranga Corona), and many of the coronae along the rift have moderate to low associated flows (Prthivi Corona and several unnamed coronae). However, since we can only map areal extent and not true volumes of flows, our ability to define the actual amount of volcanism at an individual corona is limited.

\section{Crater Material}

There are fourteen impact craters located in the $\mathrm{V}-28$ quadrangle (unit c) (table 2). Two of the craters, Nuriet and Higgins, have very unusual morphology, with an indistinct, irregular crater and outflow-like deposits. Eleven have at least partial dark floors. The dark material could be either ponded impact melt or later flood lavas (Herrick and Sharpton, 2000), or fine debris (Izenberg and others, 1994).

All but three of the craters in $\mathrm{V}-28$ are superposed on units $\mathrm{phH}$ or $\mathrm{pA}$, which are also the two most areally extensive units in the quadrangle. The crater Pat is on unit $\mathrm{pmH}$, the crater Leyster superposes units $\mathrm{psH}$ and $\mathrm{puH}$, and crater Alina superposes unit $\mathrm{fL}$. Nuriet crater is superposed on the boundary between four units (units $\mathrm{phH}, \mathrm{psH}$, fIx, and $\mathrm{pcH}$ ), Ul'yana on unit $\mathrm{pA}$ and an edifice field (unit ef), Beecher superposes both unit phH and unit $\mathrm{fT}_{\mathrm{b}}$, and the craters Gaze, Akeley, Yvette, and Higgins are on unit phH. Gaze is cut by Hecate faults, Beecher by Hanwi faults, and Wheatley and Baranamtarra are cut by faults from Zverine Chasma. Two craters are clearly superposed by other units. The crater Baranamtarra, located at lat $17^{\circ} \mathrm{N}$., long $267^{\circ} \mathrm{E}$., superposes unit pA but is covered by subsequent flows (unit fK) and cut by Zverine faults. Johanna crater superposes units $\mathrm{phH}, \mathrm{pcH}$, and $\mathrm{fT}_{\mathrm{b}}$, and is partially covered by flows from Serova Patera (unit fSe).

\section{Surficial Material}

Radar-dark, diffuse materials are mapped as surficial material (lat $8.5^{\circ} \mathrm{N}$., long $269^{\circ} \mathrm{E}$. and lat $3.5^{\circ} \mathrm{N}$., long $266.5^{\circ} \mathrm{E}$.). These deposits are interpreted to be produced upon the break-up of an impactor in the atmosphere (Phillips and others, 1991). The resulting shock wave pulverizes the upper layers of the surface, producing a roughly circular region of impact debris (Phillips and others, 1991; Zahnle, 1992), or, the shock wave may smooth the surface (Ivanov and others, 1992). In both cases in this quadrangle, no crater is visible, just a diffuse, dark patch.

\section{Structure}

In quadrangle $\mathrm{V}-28$, we have mapped structures associated with the chasmata, with coronae, and occurring in the plains. Structures are generally mapped as radar-bright lineaments, although some are mapped as wrinkle ridges on the basis of their sinuosity and similarity to wrinkle ridges on other planets (for example, Squyres and others, 1992b). All of the plains units except for $\mathrm{plH}$ and $\mathrm{psH}$ are cut by closely spaced $(<10 \mathrm{~km})$, intersecting lineaments that are at too small a scale to be represented on this 1:5,000,000-scale map (figs. 4, 5). We interpret these lineaments to be polygonal fractures, based on their similarity to polygonal fractures elsewhere on Venus (for example, Smrekar and others, 2002), but some also resemble wrinkle ridges. These sets of fractures also cut portions of volcanic unit fSo and some areas of unit vc.

Wrinkle Ridge. Wrinkle ridges are generally common on plains units on Venus (Squyres and others, 1992b; McGill, 1993; Bilotti and Suppe, 1999), and are thought to record limited amounts of horizontal shortening (for example, Plescia and Golombek, 1986). Unlike most plains regions on Venus, plains units in Hinemoa Planitia generally lack wrinkle ridges. In the southeastern portion of the map, some NNE-trending wrinkle ridges cut units $\mathrm{peH}$, fSo, and $\mathrm{phH}$. In the southwestern portion of the map, a few E-trending and ENE-trending ridges cut units $\mathrm{pmH}, \mathrm{peH}, \mathrm{puH}, \mathrm{phH}$, and $\mathrm{fG}$. Some of the closely spaced lineaments that we interpret as polygonal fractures (seen in figs. 4 and 5) may be wrinkle ridges, as discussed above.

Fracture/Fault. Radar-bright lineaments interpreted to be faults and fractures cut most of the plains units in this quadrangle. In the units immediately surrounding the chasmata, fractures generally parallel the chasma trough. Two sets of fractures occur south of the chasma: a set that trends NNE and a set that trends NNW. The NNW-trending fractures cut all of the plains units in the southern portion of the map, while the NNE-trending set is embayed in unit peH and not visible in the other plains units. The age relation between fractures associated with Hecate Chasma and the NNE-trending set is not apparent, although both sets cut units fSo and $\mathrm{phH}$. The three orientations of fracture sets indicate that different episodes of regional-scale tensional stress have affected this quadrangle at multiple times throughout its visible history. To the north of the chasmata, no regional sets of fractures occur. Most of these fractures are spatially related to local features such as volcanic centers or coronae.

Chasmata. Hecate Chasma extends for over $8000 \mathrm{~km}$, from Atla Regio through Asteria Regio (Hamilton and Stofan, 1996). Hecate Chasma is a discontinuous trough and fracture system, with en echelon offset along its trend. Regions where the trough is topographically distinct in this quadrangle (for example, near Kono Mons versus southwest of Polik-mana Mons) tend to be characterized by more dense fracture spacing (Hamilton and Stofan, 1996), as at the sections of the chasma system in the $\mathrm{V}-28$ quadrangle. The origin of chasma systems has been a subject of debate, with hypotheses ranging from extension and associated diapiric upwelling (Stofan and others, 1992; Hansen and Phillips, 1993) to subduction (Schubert and others, 1994; Schubert and Sandwell, 1995). We favor an extensional origin, 
on the basis of similarities of the chasmata to terrestrial rift systems.

Three branches of the Hecate system are contained in this quadrangle: Hecate Chasma, Hanwi Chasma, and Zverine Chasma. All three of these branches have troughs ranging from $<500 \mathrm{~m}$ deep to over $2 \mathrm{~km}$ deep. The zone of fractures tends to extend beyond the trough. In places along each chasma, the fractures are closely spaced, and in other places the fractures are more widely spaced and tend to be slightly sinuous. Zverine Chasma appears to postdate the main Hecate Chasma, as it terminates abruptly against it, suggesting that Hecate acted as a structural barrier to Zverine. Hanwi Chasma does not have a clear age relation with the other two branches. Each chasma could have formed simultaneously, or may have formed at quite different times.

\section{Geologic History}

The geologic history of the $\mathrm{V}-28$ quadrangle is dominated by formation of the chasmata, coronae, and volcanic edifices and flows. We can identify no regional-scale plains units; the numerous plains units appear to be local units. The plains units are interpreted to be volcanic in origin based on their lobate boundaries, the association with volcanic source vents (that is, edifices), and the generally accepted view that plains on Venus are volcanic in origin (for example, Head and others, 1992). Identifying different plains units in the vicinity of the chasmata and across the chasmata is extremely difficult, owing to the close spacing of the fractures. Therefore, we do not feel overly confident of the age relation or continuity of plains units mapped in the immediate vicinity of the chasmata.

In addition, as described above, most units in the $\mathrm{V}-28$ map area are not in contact, leading us to formulate a correlation chart that is extremely horizontal, with most units having hachured tops and bottoms indicating uncertainty in the timing and extent of their formation. The horizontality of this chart should not be misconstrued to indicate that the units all formed simultaneously, rather, it reflects our inability to place the units with any confidence in a more specific stratigraphic sequence, with the exception of some of the events described below. Therefore, a number of geologic histories could be constructed for this quadrangle, most of which are not testable in the absence of age dating of surface rocks (for example, Stofan and others, 2005).

The earliest history of this quadrangle is preserved in a number of units (units peH, pfH, t) found to the north and south of Hecate Chasma. These units are all deformed to varying degrees; in general, they are more deformed than younger plains units. Their original character is not clear; unit peH is interpreted to be of volcanic origin, affected by later, possibly multiple episodes of tectonic and volcanic activity. The materials that make up the highly deformed units $\mathrm{pfH}$ and $\mathrm{t}$ are of unknown origin. The amount of time represented by these units, and whether they represent earlier episodes of rift formation and volcanism in this region, is not clear. A good example of the complexity of older plains units is unit $\mathrm{peH}$, which embays a set of NNE-trending fractures, and is cut by Hecate Chasmata fractures and a NNW-trending set of fractures. The unit is overlain by younger edifices and coronae, and contains both embayed and superposed small edifices. This multi-staged history of unit peH took place over an unknown amount of time.

Later plains units of relatively limited areal extent (units $\mathrm{phH}, \mathrm{pcH}, \mathrm{puH}$ ) were then formed by volcanic processes. These units are interpreted to be volcanic on the basis of their general morphology, numerous lobate patches that are either too small to be mappable units or do not have complete boundaries, and overall lobate boundaries. The only visible sources for these units are small edifices, although it is likely that many flows originated at fissures that have been covered by subsequent flows. Secondary structures on these units are primarily polygonal fractures and fractures associated with Hecate Chasmata, in particular, unit phH.

Volcanism and coronae formation occurred prior to, during and after formation of Hecate Chasmata. Evidence of this is seen at Kono Mons, which was split by the rift (portions of the edifice are located on the north and south rift flank) and yet continued to erupt as extension associated with the rift continued (that is, Kono flows are cut by rift-associated fractures) (fig. 6). In addition, crosscutting and superposition relations between chasma-associated fractures and flows of Polik-mana Mons indicate that formation of this volcano overlapped in time with the formation of Hecate Chasma. At Taranga Corona, the corona appears to largely postdate formation of Hecate Chasma, as it is largely superposed on the rift, but some Taranga flows are cut by chasma-associated fractures. We see no clear progression in the relative age of coronae and volcanoes along the rift. In addition, the volcanic edifices and coronae occur in a broad zone extending from several hundred kilometers north of the rift to over 500 $\mathrm{km}$ south of the rift, not just directly on the rift. If the rift and coronae are a result of mantle upwelling, as has been interpreted by several previous workers (for example, Chapman and Zimbelman, 1998; Stofan and Smrekar, 2005), and coronae are favored to form in association with upwellings (for example, Johnson and Richards, 2003), then the underlying process of upwelling is occurring at a broader scale than the rift itself (Martin and others, 2007). Both this broader zone and the rift might be caused by extension of the lithosphere, but they have occurred at two different scales. Segmentation of the rift at Devana Chasma, to the east of the V-28 map area, has been interpreted to indicate that the system formed as two distinct rifts over two intersecting mantle plumes (Kiefer and Swafford, 2006); the multiple segments of Hecate do not have any simple geometric pattern that would indicate a similar mechanism of origin.

Volcanic features occur in a broad zone across the map. Edifice fields in the region appear to be relatively young based on superposition relations, and all of the plains units, particularly those to the south of the rift, tend to have high concentrations of small edifices. As described above, individual small edifices, both within edifice fields and within plains units, appear to have formed at different times, based on cross-cutting relations with local structures (fig. 4). The southern half of quadrangle $\mathrm{V}-28$ has a high concentration of small and intermediate volcanoes, and lies within the Beta-Atla-Themis (BAT) region, the so-called BAT region, which was previously identi- 
fied as having the highest regional concentration of volcanic features on Venus (Crumpler and others, 1997).

In this quadrangle, volcanic features are abundant along the chasmata and in the plains to the south. For example, Taranga Corona on Hecate Chasma has extensive flows, as do Sinlaku and Aruru Coronae which lie to the south of Hecate. A few flow materials units are directly associated with the chasma (unit $\mathrm{fH}$ and possibly unit fSo), but they are smaller in areal extent than volcanic units to the south of the chasma. The highest concentration of small edifices is to the south of Hecate Chasma; only a few edifices are located on the rift. If extension enhances volcanism in this region (for example, Magee and Head, 1995), then volcanic features should occur in higher abundance along the rift in comparison to the surrounding regions. However, a larger number of volcanic features occur south of the rift rather than along the rift. In this region, we interpret that upwelling and lithospheric extension have produced volcanism that occurred (and may be occurring) over a broad region that includes the rift, but also extends to the north (to a limited extent) and to the south.

On Venus, only about 17 percent of the total population of impact craters are either volcanically embayed and (or) deformed (Schaber and others, 1992). In this quadrangle, 38 percent of craters are embayed or deformed (table 2). For example, in V-28, one crater is cut by faults from Hecate Chasma, one by Zverine Chasma faults, one by Hanwi Chasma faults, another is cut by Zverine faults and embayed by flows, and another (Johanna) is embayed by flows from Serova Patera. We have identified one more embayed and deformed crater than was listed in the Schaber and others (1998) database (Johanna). We also do not include in the embayed population the number of dark-floored craters (for example, Herrick and Sharpton, 2000); therefore, we would argue that the 38 percent is likely to be an underestimate. Although detailed mapping is likely to raise the number of deformed and embayed craters on Venus, the $\mathrm{V}-28$ region contains an anomalously high number of affected craters, a possible indication that this region has been more recently geologically active.

Two end-member models have been proposed for Venus: a directional model in which specific types of features formed globally at specific times (Basilevsky and Head, 1995, 1998; Head and Basilevsky, 1998; Ivanov and Head, 2001), and a nondirectional model in which types of geologic features form over the range of observable Venus history (Guest and Stofan, 1999; Stofan and others, 2005). An exception to the non-directional model is tessera; most workers agree that the majority of tessera plateaus (large-scale, high standing areas of tessera such as Alpha Regio to the southeast of the V-28 map area) seem to predate the plains that immediately surround them (for example, Ivanov and Head, 1996; Hansen and Willis, 1996). V-28 contains no tessera plateaus. The fragments of tessera-type terrain in the quadrangle are relatively older than the units with which they are in contact, but the fragments are small, and only in contact with units $\mathrm{pA}, \mathrm{pcH}, \mathrm{phH}$, and $\mathrm{fT}_{\mathrm{b}}$. Hypotheses for fragments of tessera range from an old, widespread unit that underlies much of the plains (for example, Ivanov and Head, 1996) to the tessera fragments forming at different times by different mechanisms (Hansen and Willis, 1996). The three outcrops of tessera in quadrangle $\mathrm{V}-28$ are in close proximity $(\sim 100 \mathrm{~km})$, suggesting that they once formed a larger unit that extended for over $400 \mathrm{~km}$ x $500 \mathrm{~km}$. However, the origin of this unit and the age of it relative to the other "old" plains units (unit peH, unit $\mathrm{pfH}$ ) in this quadrangle are not known.

Plains, volcano, and corona units in this quadrangle are more consistent with a non-directional model, with the important caveat that we are looking at a small portion of Venus representing an unknown amount of time. With respect to plains units, we see no evidence here for a widespread episode of resurfacing as described by the directional model; instead the patch-like, composite character of the $\mathrm{V}-28$ plains units (including units $\mathrm{peH}$, $\mathrm{phH}, \mathrm{pcH}$, and $\mathrm{pA}$ ) support incremental resurfacing over time in this region (for example, Phillips and others, 1992), consistent with the non-directional model. Edifices (large and intermediate volcanoes, as well as small volcanoes) have formed throughout the history of the quadrangle, both pre- and post-dating rift formation (for example, fig. 6) and corona formation, again consistent with predictions of the non-directional rather than the directional model, which has specific episodes of small and large volcano formation (for example, Basilevsky and Head, 1995). Corona flows predate units $\mathrm{pmH}$ and $\mathrm{psH}$, and formation of a corona has overlapped in time with the formation of units $\mathrm{peH}$ and $\mathrm{pmH}$. Again, the occurrence of corona units throughout the visible history of this quadrangle is inconsistent with the directional model, which confined corona formation to specific time periods (for example, Basilevsky and others, 1997). Multiple episodes of tensional stress have occurred, early in the history of the quadrangle (unit $\mathrm{pfH}$ ) and at some later time with the formation of the multiple branches of Hecate and the NNW-trending fractures. However, while the formation of chasma, coronae, volcanoes, and plains units have overlapped in time, consistent with the non-directional model, we still have no ability to determine the duration of any of these events. While the overall surface of Venus has an average crater retention age of $\sim 750$ m.y. (McKinnon and others, 1997), the inability to distinguish the Venus crater population from a random population prevents determination of ages of individual units (Campbell, 1999).

\section{References Cited}

Addington, E.A., 2001, A stratigraphic study of small volcano clusters on Venus: Icarus, v. 149, p. 16-36.

Aittola, M., and Raitala, J., 2005, Coronae and novae in the Hecate Chasma deformation area: Solar System Research, v. 39, p. 199-213.

Barsukov, V., and 29 authors, 1986, The geology and geomorphology of the Venus surface as revealed by the radar images obtained by Veneras 15 and 16: Journal of Geophysical Research, v. 91(B4), p. D378-D398.

Basilevsky, A.T., and Head, J.W., 1995, Global stratigraphy of Venus - Analysis of thirty-six test areas: Earth, Moon, and Planets, v. 43, p. 285-336.

Basilevsky, A.T., and Head, J.W., 1998, The geologic history of Venus-A stratigraphic view: Journal of Geophysical Research, v. 103, p. 8531-8544. 
Basilevsky, A.T., Head, J.W., Schaber, G.G., and Strom, R.G., 1997, The resurfacing history of Venus, in Bouger, S.W., Hunten, D.M., and Phillips, R.J., eds., Venus II-Geology, geophysics, atmosphere and solar environment: Tucson, The University of Arizona Press, p. 1047-1084.

Bilotti, F., and Suppe, J., 1999, The global distribution of wrinkle ridges on Venus: Icarus, v. 139, p. 137-157.

Campbell, B.A., 1995, Use and presentation of Magellan quantitative data in Venus mapping: U.S. Geological Survey Open-File Report 95-519, 27 p.

Campbell, B.A., 1999, Surface formation rates and impact crater densities on Venus: Journal of Geophysical Research, v. 104, p. 21,951-21,955.

Campbell, B.A., and Campbell, D.B., 1992, Analysis of volcanic surface morphology on Venus from comparisons of Arecibo, Magellan and Terrestrial airborne radar data: Journal of Geophysical Research, v. 97, p. 16,293-16,314.

Chapman, M.G., 1999, Geologic map of the Galindo Quadrangle (V-40), Venus: U.S. Geological Survey Geological Investigations Series I-2613, scale 1:5,000,000.

Chapman, M.G., and Zimbelman, J.R., 1998, Corona associations and their implications for Venus: Icarus, v. 132, p. 344-361.

Crumpler, L.S., Aubele, J.C., Senske, D.A., Keddie, S.T., Magee, K.P., and Head, J.W., 1997, Volcanoes and centers of volcanism on Venus, in Bougher, S.W., Hunten, D.M., and Phillips, R.J., eds., Venus II-Geology, geophysics, atmosphere and solar environment: Tucson, The University of Arizona Press, p. 697-756.

Ford, J.P., and 7 others, 1993, Guide to Magellan Image Interpretation: Pasadena, Calif., National Aeronautics and Space Administration Jet Propulsion Laboratory Publication, 93-24, $287 \mathrm{p}$.

Ford, P.G., and Pettengill, G.H., 1992, Venus topography and kilometer-scale slopes: Journal of Geophysical Research, v. 97, p. 13,103-13,114.

Guest, J.E., Bulmer, M.H., Aubele, J., Beratan, K., Greeley, R., Head, J.W., Michaels, G., Weitz, C., and Wiles, C., 1992, Small volcanic edifices and volcanism in the plains of Venus: Journal of Geophysical Research, v. 97, p. 15,94915,966 .

Guest, J.E., and Stofan, E.R., 1999, A new view of the stratigraphic history of Venus: Icarus, v. 139, p. 55-66.

Hamilton, V.E., and Stofan, E.R., 1996, The geomorphology and evolution of Hecate Chasma, Venus: Icarus, v. 121, p. 171-194.

Hansen, V.L., 2000, Geologic mapping of tectonic planets: Earth Planetary Science Letters, v. 176, p. 527-542.

Hansen, V.L., 2006, Geologic constraints on crustal plateau surface histories, Venus - The lava pond and bolide impact hypotheses: Journal of Geophysical Research, v. 111, (doi:10.1029/2006JE002714).

Hansen, V.L., and Phillips, R.J., 1993, Tectonics and volcanism of eastern Aphrodite Terra, Venus-No subduction, no spreading: Science, v. 260, p. 526-530.

Hansen, V.L., and Willis, J.J., 1996, Structural analysis of a sampling of tesserae-Implications for Venus geodynamics: Icarus, v. 123, p. 296-312.
Hansen, V.L., and Willis, J.J., 1998, Ribbon terrain formation, Southwestern Fortuna Tessera, Venus-Implications for lithosphere evolution: Icarus, v. 132, p. 321-343.

Head, J.W., and Basilevsky, A.T., 1998, Sequence of tectonic deformation in the history of Venus - Evidence from global stratigraphic relationships: Geology, v. 26, p. 35-38.

Head, J.W., Crumpler, L.S., Aubele, J.C., Guest, J.E., and Saunders, R.S., 1992, Venus volcanism-Classification of volcanic features and structures, associations, and global distribution from Magellan data: Journal of Geophysical Research, v. 97, p. 13,153-13,197.

Herrick, R.R., and Sharpton, V.L., 2000, Implications from stereo-derived topography of Venusian impact craters: Journal of Geophysical Research, v. 105, p. 20,245-20,262.

Ivanov, M.A., and Head, J.W., 1996, Tessera terrain on VenusA survey of the global distribution, characteristics, and relation to surrounding units from Magellan data: Journal of Geophysical Research, v. 101, p. 14,861-14,908.

Ivanov, M.A., and Head, J.W., 2001, Geology of Venus-Mapping of a global geotraverse at 30N: Journal of Geophysical Research, v. 106, p. 17,515-17,566.

Ivanov M.A., and Head, J.W., 2004, Stratigraphy of small shield volcanoes on Venus - Criteria for determining stratigraphic relationships and assessment of relative age and temporal abundance: Journal of Geophysical Research, v. 109, (doi:10.1029/2004JE002252).

Ivanov, B.A., Nemchinov, I.V., Svetsov, V.A., Provalov, A.A., Khazins, V.M., and Phillips, R.J., 1992, Impact cratering on Venus-Physical and mechanical models: Journal of Geophysical Research, v. 97, p. 16,167-16,182.

Izenberg, N., Arvidson, R.E., and Phillips, R.J., 1994, Impact crater degradation on venusian plains: Geophysical Research Letters, v. 21, p. 289-292.

Johnson, C.L., and Richards, M.A., 2003, A conceptual model for the relationship between coronae and large-scale mantle dynamics on Venus: Journal of Geophysical Research, v. 108, (doi:10.1029/2002JE001962).

Kasting, J.F., and Pollack, J.B., 1983, Loss of water from Venus 1. Hydrodynamic escape of hydrogen: Icarus, v. 53, p. 479-508.

Kiefer, W.S., and Peterson, K., 2003, Mantle and crustal structure in Phoebe Regio and Devana Chasma, Venus: Geophysical Research Letters, v. 30, (doi:10.1029/2002GL015762).

Kiefer, W.S., and Swafford, L.C., 2006, Topographic analysis of Devana Chasma, Venus - implications for rift system segmentation and propagation: Journal of Structural Geology, v. 28, p. 2144-2155.

Lancaster, M.G., Guest, J.E., and Magee, K.P., 1995, Great lava flow fields on Venus: Icarus, v. 118, p. 69-86.

Magee, K.P., and Head, J.W., 1995, The role of rifting in the generation of melt-Implications for the origin and evolution of the Lada Terra-Lavinia Planitia region of Venus: Journal of Geophysical Research, v. 100, p. 1527-1552.

Magee, K.P., and Head, J.W., 2001, Large flow fields on Venus-Implications for plumes, rift associations and resurfacing: Geological Society of America Special Paper, v. 352, p. 81-101. 
Martin, P., Stofan, E.R., Glaze, L.S., and Smrekar, S.E., 2007, Coronae of Parga Chasma, Venus: Journal of Geophysical Research, v. 112, (doi:10.1029/2006JE002758).

Masursky, H., Eliason, E., Ford, P.G., McGill, G.E., Pettengill, G.H., Schaber, G., and Schubert, G., 1980, Pioneer-Venus radar results - geology from images and altimetry: Journal of Geophysical Research, v. 85, p. 8232-8260.

McGill, G.E., 1993, Wrinkle ridges, stress domains, and kinematics of venusian plains: Geophysical Research Letters, v. 20, p. 2407-2410.

McKinnon, W.B., Zahnle, K.J., Ivanov, B.A., and Melosh, H.J., 1997, Cratering on Venus-Models and observations, in Bougher, S.W., Hunten, D.M., and Phillips, R.J., eds., Venus II-Geology, geophysics, atmosphere and solar environment: Tucson, The University of Arizona Press, p. 969-1014.

Pettengill, G.H., Ford, P.G., and Wilt, R., 1992, Venus surface radiothermal emission as observed by Magellan: Journal of Geophysical Research, v. 97, p. 13,091-13,102.

Phillips, R.J., Arvidson, R.E., Boyce, J.M., Campbell, D.B., Guest, J.E., Schaber, G.G., and Soderblom, L.A., 1991, Impact craters on Venus-Initial analysis from Magellan: Science, v. 252, p. 288-297.

Phillips, R.J., Raubertas, R.F., Arvidson, R.E., Sarkar, I.C., Herrick, R.R., Izenberg, N., and Grimm, R.E., 1992, Impact craters and Venus resurfacing history: Journal of Geophysical Research, v. 97, p. 15,923-15,948.

Plescia, J.B., and Golombeck, M.P., 1986, Origin of planetary wrinkle ridges based on study of terrestrial analogs: Geological Society of America Bulletin, v. 97, p. 1289-1299.

Roberts, K.M., Guest, J.E., Head, J.W., and Lancaster, M.G., 1992, Mylitta Fluctus, Venus - Rift-related centralized volcanism and the emplacement of large-volume flow units: Journal of Geophysical Research, v. 97, p. 15,991-16,015.

Saunders, R.S., Arvidson, R., Head, J.W., Schaber, G., Solomon, S., and Stofan, E., 1991, Magellan-A first overview of Venus geology: Science, v. 252, p. 249-252.

Schaber, G.G., Kirk, R.L., and Strom, R.G., 1998, Data Base of impact craters on Venus based on analysis of Magellan radar images and altimetry data: U.S. Geological Survey Open-File Report 98-104.

Schaber, G.G., Strom, R.G., Moore, H.J., Soderblom, L.A., Kirk, R.L., Chadwick, D.J., Dawson, D.D., Gaddis, L.R., Boyce, J.M., and Russell, J., 1992, Geology and distribution of impact craters on Venus - What are they telling us?: Journal of Geophysical Research, v. 97, p. 13,25713,302 .

Schubert, G., Moore, W.B., and Sandwell, D.T., 1994, Gravity over coronae and chasmata on Venus: Icarus, v. 112, p. $130-146$.

Schubert G., and Sandwell, D.T., 1995, A global survey of possible subduction sites on Venus: Icarus, v. 117, p. 173-196.

Smrekar, S.E., Moreels, P., Franklin, B.J., 2002, Characterization and origin of polygonal fractures on Venus: Journal of Geophysical Research, v. 107, (doi: 10.1029/2001JE001808).

Squyres, S.W., Janes, D.M., Baer, G., Bindschadler, D.L., Schubert, G., Sharpton, V.L., Stofan, E.R., 1992a, The morphology and evolution of coronae on Venus: Journal of Geophysical Research, v. 97, p. 13,611-13,634.

Squyres, S.W., Jankowski, D.G., Simons, M., Solomon, S.C., Hager, B.H., and McGill, G.E., 1992b, Plains tectonism on Venus - The deformation belts of Lavinia Planitia: Journal of Geophysical Research, v. 97, p. 13,579-13,610.

Stofan, E.R., Brian, A.W., and Guest, J.E., 2005, Resurfacing styles and rates on Venus - Assessment of 18 venusian quadrangles: Icarus, v. 173, p. 312-321.

Stofan, E.R., Guest, J.E., and Copp, D.L., 2001a, Development of large volcanoes on Venus - Constraints from Sif, Gula and Kunapipi Montes: Icarus, v. 152, p. 75-95.

Stofan, E.R., Hamilton, V.E., Janes, D.M., and Smrekar, S.E., 1997, Coronae on Venus - Morphology and origin, in Bougher, S.W., Hunten, D.M., and Phillips, R.J., eds., Venus II-Geology, geophysics, atmosphere and solar environment: Tucson, The University of Arizona Press, p. 931-965.

Stofan, E.R., Head, J.W., Campbell, D.B., Zisk, S.H., Bogomolov, A.F., Rzhiga, O.N., Basilevsky, A.T., and Armand, N., 1989, Geology of a Venus rift zone-Beta Regio and Devana Chasma: Geological Society of America Bulletin, v. 101, p. 143-156.

Stofan, E.R., Sharpton, V.L., Schubert, G., Baer, G., Bindschadler, D.L., Janes, D.M., and Squyres, S.W., 1992, Global distribution and characteristics of coronae and related features on Venus-Implications for the origin and relation to mantle processes: Journal of Geophysical Research. v. 97, p. 13,347-13,378.

Stofan, E.R., and Smrekar, S.E., 2005, Large topographic rises, coronae, large flow fields and large volcanoes on VenusEvidence for mantle plumes?, in Foulger, G.R., Natland, J.H., Presnall, D.C., and Anderson, D.L., eds., Plumes, plates and paradigms: Geological Society of America Special Volume 388, p. 841-861.

Stofan, E.R., Smrekar, S.E., Tapper, S.W., Guest, J.E., and Grindrod, P.M., 2001b, Preliminary analysis of an expanded corona database for Venus: Geophysical Research Letters, v. 28, p. 4267-4270.

Surkov, Yu. A., Barsukov, V.L., Moskalyeva, L.P., Kharyukova, V.P., and Kemurdzhian, A.L., 1984, New data on the composition, structure and properties of Venus rock obtained by Venera 13 and Venera 14: Journal of Geophysical Research, v. 89, p. B393-B402.

Tanaka, K.L., 1994, The Venus geologic mappers' handbook: U.S. Geological Survey Open-File Report 94-438, 48 p.

Wilhelms, D.E., 1972, Geologic mapping of the Second Planet: U.S. Geological Survey Interagency Report, Astrogeology, v. $55,36 \mathrm{p}$.

Wilhelms, D.E., 1990, Geologic mapping, in Greeley, R., and Batson, R.M., eds., Planetary mapping: New York, Cambridge University Press, 296 p.

Zahnle, K.J., 1992, Airburst origin of dark shadows on Venus: Journal of Geophysical Research, v. 97, p. 10,243-10,255.

Zimbelman, J.R., 2001, Image resolution and evaluation of genetic hypotheses for planetary landscapes: Geomorphology, v. 37, p. 179-199. 
Table 1. Coronae of V-28.

\begin{tabular}{lcccll}
\hline \multicolumn{1}{c}{ Name } & Latitude $\left({ }^{(} \mathbf{N}\right)$ & Longitude $\left({ }^{\circ} \mathbf{E}\right)$ & Maximum Width $(\mathbf{k m})$ & Type & Topopgraphy \\
\hline Tari Pennu & 0 & 264.5 & 200 & concentric & rim only \\
unnamed & 0.7 & 254.8 & 110 & concentric-double ring & raised, irregular \\
Rind & 8 & 247.5 & 150 & concentric & rimmed depression \\
Aruru & 9 & 262 & 450 & asymmetric & rimmed plateau \\
Ak-Ene & 9.5 & 254.5 & 150 & concentric-double ring & rim only \\
unnamed & 10 & 246 & 200 & concentric-double ring & rimmed depression \\
unnamed & 10.5 & 251.5 & 300 & concentric & rimmed depression \\
Prthivi & 11 & 248.5 & 300 & concentric & rimmed depression \\
Gashan-Ki & 11.5 & 244 & 290 & concentric & raised, irregular \\
unnamed & 13.5 & 253 & 200 & concentric & rimmed depression \\
unnamed & 14 & 254.5 & 125 & concentric & depression \\
unnamed & 14 & 256.5 & 180 & concentric & depression \\
Nei-Teukez & 14 & 258.8 & 125 & concentric & rimmed depression \\
Taranga & 16.5 & 251.5 & 525 & asymmetric & rimmed plateau \\
Sinlaku & 17.5 & 260.5 & 300 & concentric & rimmed plateau \\
unnamed & 19.5 & 265.5 & 150 & concentric & raised, irregular \\
unnamed & 22.5 & 256.7 & 150 & asymmetric & raised, irregular \\
Acrea & 24 & 243.5 & 500 & multiple & rimmed depression \\
\hline
\end{tabular}

Table 2. Impact craters of V-28.

\begin{tabular}{|c|c|c|c|c|c|c|}
\hline Name & $\begin{array}{l}\text { Latitude } \\
\qquad\left({ }^{\circ} \mathrm{N}\right)\end{array}$ & $\begin{array}{c}\text { Longitude } \\
\left({ }^{\circ} \mathrm{E}\right)\end{array}$ & $\begin{array}{c}\text { Diameter } \\
(\mathbf{k m})\end{array}$ & Description & Superposed on: & Superposed by: \\
\hline Ulyana & 24.3 & 253 & 13 & bright floor with dark flow, central peak & ef, $p A$ & \\
\hline Nuriet & 21 & 245.5 & 16 & partial dark floor & $\underset{\mathrm{flx}}{\mathrm{pcH}, \mathrm{psH}}, \mathrm{phH}$, & \\
\hline Johanna & 19.5 & 247.3 & 15.9 & bright floor & $\mathrm{fT}_{\mathrm{b}}, \mathrm{phH}, \mathrm{pcH}$ & fSe \\
\hline Baranamtarra & 17.9 & 267.8 & 25.6 & dark floor, central peak & $\mathrm{pA}$ & $\mathrm{fK}$, Zverine faults \\
\hline Montez & 17.9 & 266.5 & 18.2 & dark floor, central peak & $\mathrm{pA}$ & \\
\hline Gaze & 17.9 & 240.1 & 32.9 & bright floor & $\mathrm{phH}$ & Hecate faults \\
\hline Wheatley & 16.6 & 268 & 72.9 & dark floor, inner ring & $\mathrm{pA}$ & Zverine faults \\
\hline Beecher & 13.1 & 253.5 & 42.8 & bright floor with dark flow, central peak & $\mathrm{fT}_{\mathrm{b}}, \mathrm{phH}$ & Hanwi faults \\
\hline Akeley & 8 & 244.5 & 22.7 & central peak, partial dark floor & phH & \\
\hline Yvette & 7.4 & 249.6 & 10.4 & dark floor & $\mathrm{phH}$ & \\
\hline Higgins & 7 & 242 & 33.3 & multiple small craters, partial dark floor & $\mathrm{phH}$ & \\
\hline Pat & 2.9 & 262.6 & 11.1 & bright floor with dark flow, central peak & $\mathrm{pmH}$ & \\
\hline Leyster & 1 & 260 & 45.1 & dark floor, inner ring & $\mathrm{psH}, \mathrm{puH}$ & \\
\hline
\end{tabular}

